\title{
What Language was Spoken by the People of the Bactria-Margiana Archaeological Complex?
}

\author{
Alexander Lubotsky
}

Albert Hoffstädt was the architect of a unique cooperation between Brill publishers and the Leiden Department of Comparative Indo-European Linguistics, a cooperation that has so far resulted in a series of twelve etymological dictionaries and an online publication of fifteen etymological databases (<https://dictionaries.brillonline.com/iedo $>$ ). In all the years that Albert was directly involved in the Indo-European Etymological Dictionary project, we often had discussions about languages and cultures of long-gone civilizations and about the linguistic methodology for reconstructing them. It is therefore my pleasure to offer in his honor some considerations about the language of an intriguing new civilization, relatively recently discovered in Central Asia.

The Russian archaeologist V.I. Sarianidi has localized dozens of settlements on the territory of former Margiana and Bactria and has proven that they belong to the same archaeological culture, which he labeled "Bactria-Margiana Archaeological Complex" (B MAC). At the end of the 1970s he managed to find the probable capital of this culture, a settlement called Gonur-depe. Gonur is located in the old delta of the Murghab River, on the border of the Karakum desert. The city was most likely founded around 2300 ВСЕ and experienced its heyday between 2000 and 1800 . Somewhere around 1800 , the riverbed of the Murghab began to move eastwards, which eventually led to the city being abandoned by its inhabitants. Already very soon the whole BмAC civilization started to decline, and we see few traces of it after 16оо BCE.

At the beginning of the second millennium, Gonur was one of the largest cities in the world. The citadel alone with its royal palace, temples and surrounding buildings occupies an area of ten hectares. The city also included a separate temple complex (the so-called Temenos), a $1.5 \mathrm{sq} . \mathrm{km}$ necropolis with about three thousand burials, water reservoirs, squares, hundreds of artisan's houses, etc. Since there was no stone nearby and hardly any wood, the whole city was built of unbaked bricks: clay was mixed with straw, put into special forms and dried in the sun. 
Over the forty years of excavation of Gonur, a wealth of material has been collected about the cityl: we learned about its luxurious architecture, the highest level of its artisans - potters, metallurgists, jewelers-, the complex temple and funeral rituals, the extensive contacts with the civilizations of Mesopotamia and the Indus. And the more we learn about this wonderful culture, the more urgent the question becomes: where did the people who created it come from, what language did they speak? Can linguists contribute to the discussion on this subject?

At first glance, this question may seem premature, because, despite all efforts, archaeologists have not yet been able to find any written documents either in Gonur or in other settlements of the civilization of Bactria and Margiana. Nevertheless, it seems possible to draw some linguistic conclusions.

In discussions about possible candidates for founding the BMAC, we often come across Indo-Iranians or Aryans. For example, Sarianidi himself was convinced that they were the ones who founded Gonur. ${ }^{2}$ Who were the Aryans and what could be their involvement with this civilization?

The Indo-Iranian languages belong to the Indo-European language family and are divided into two branches: Indian and Iranian. The main representative of the Indian branch is Sanskrit, the language of the Vedas, the oldest of which, the Rigveda, was created around 1200 вСЕ. The Iranian languages include primarily Avestan (the sacred language of the Zoroastrians, around 1000 BCE) and Old Persian, the language of inscriptions of the Achaemenid kings (VI-V century вCE). Among modern Iranian languages the best known ones are Persian (Farsi), Tajik, Pashto, Kurdish (See Fig. 1.1).

The breakdown of the Indo-Iranian branch into Indian and Iranian occurred somewhere between 2000 and 1600 bce, when future Indians left their tribesmen and crossed the Hindu Kush on their way to India. Before that, IndoIranians had lived in Central Asia. We can thus conclude that the Indo-Iranians or Aryans (as they called themselves) were not far from Gonur when it was founded around 2300 BCE. Nevertheless, I am convinced that the Aryans had nothing to do with the foundation of this city.

As a matter of fact, linguists can describe the life and culture of a people in some detail on the basis of its vocabulary. The idea of the method is fairly simple. Consider, for instance, the Germanic words for 'bread': Old Norse brauð,

1 V.I. Sarianidi, Маргуш:Древневосточное царство в старой дельте реки Мургаб (= Margush: TheAncientKingdomin the OldDeltaof the MurghabRiver) (Ashgabad:Turkmendöwlethabarlary 2002); V.I. Sarianidi, Гонур-депе, город царей и богов (= Gonur-depe, city of kings and gods) (Ashgabat: Turkmendöwlethabarlary, 2006).

2 See Victor Sarianidi, Margiana and Protozoroastrizm (Athens: Kapon edition, 1998) and idem, Necropolis of Gonur (Athens: Kapon edition, 2007). 


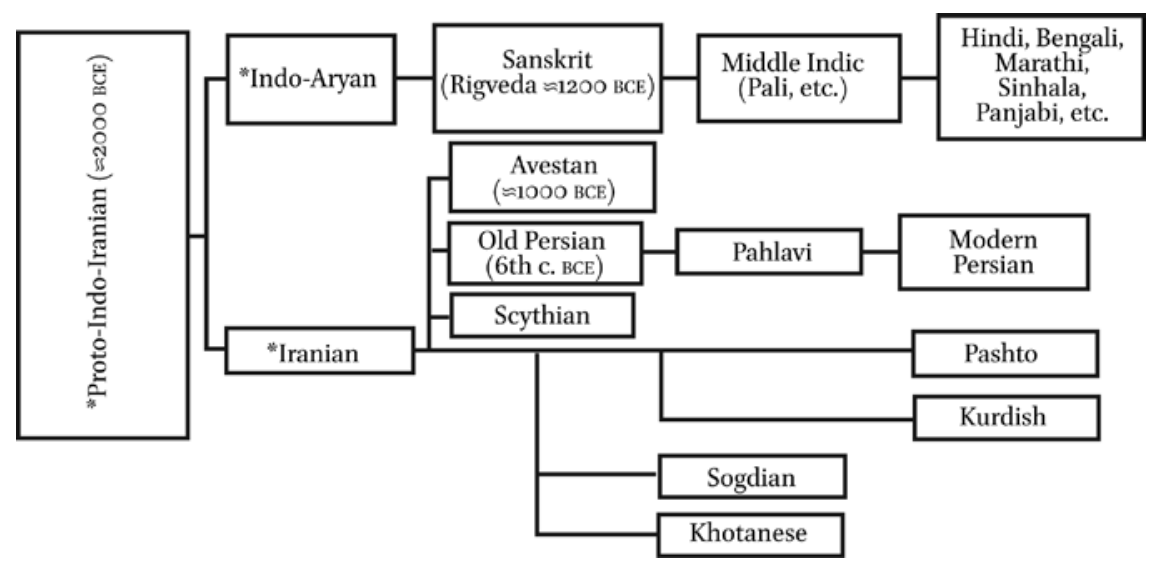

FIGURE 1.1 Genealogical tree of Indo-Iranian languages

Old English brēad, English bread, Old Frisian brād, Old Saxon brōd, Dutch brood, Old High German brōt, German Brot. It is clear that all these terms are related and go back to a Proto-Germanic word which looked something like *brauda-. With some degree of certainty we can assign it the meaning 'bread' and assume that the Proto-Germans in the first century BCE had a kind of bread, although we do not know either its recipe or the flour it was made of. However, on the basis of morphology, we can conclude that since this *braudaevidently is a derivative of the verb *brewwan- 'to brew', the Proto-Germans must have already used yeast to bake the bread.

If we apply this method to the Indo-Iranian vocabulary, we come to the undeniable conclusion that the Aryans were nomadic pastoralists. They had dozens of words related to horses, harness, chariots, all sorts of cattle, and very limited agricultural terminology. Besides, there were practically no terms in their language relating to permanent houses, let alone words like 'palace' or 'temple'. The only conclusion we can draw is that the Aryans were simply unable to build a city like Gonur. Moreover, they as nomads did not even need such a city.

Therefore, most scholars believe that the Indo-Iranian way of life much better matches the Andronovo archaeological culture, which was located north and east of Bactria and Margiana. ${ }^{3}$ The Andronovans lived in the steppes, raised horses and cattle, and used chariots, whereas farming played a relatively

3 See Elena E. Kuz'mina, The Origin of the Indo-Iranians (Leiden: Brill, 2007). 
small role in their lives. Importantly, Andronovans maintained intensive contacts with farmers in Bactria and Margiana: archaeologists have established that by the beginning of the second millennium $\mathrm{BCE}$, each BMAC settlement was surrounded by Andronovo camps. ${ }^{4}$ If the Andronovans were indeed Aryans, then these contacts should have left traces in the Proto-Indo-Iranian language in the form of loanwords. In order to identify these traces, we must analyze the Indo-Iranian vocabulary in search of foreign elements.

Loanwords often have an unusual form in the target language. So, if an English word contains a $z$ (e.g., zen, zeal, frenzy) or it ends in -tion (revolution, civilization), we can tell with confidence that this word is borrowed.

Thus, we must find Indo-Iranian words that meet the following conditions:

1. The word is found in both Indian and Iranian languages, so it probably existed in the common Indo-Iranian period.

2. The word has no Indo-European etymology, i.e., it has no cognates in other Indo-European languages.

3. The word has an unusual appearance.

As it turns out, there are several dozens of such words, ${ }^{5}$ and if our previous inferences are correct, these are exactly the words that the Aryans may have borrowed from the Bactria-Margiana language. In this unusual way, we can for the first time get to know the language spoken in Gonur, at least partially.

What words did the Aryans borrow from the Gonur people? These are, above all, words related to house construction: *jharmya 'permanent house (i.e., not a yurt),' *ištya 'brick, clay', *sikatā 'sand, gravel', *mayūkha 'wooden pin'. Of course, the nomads who lived in yurts had a lot to learn from the architects of Gonur and other cities.

They also borrowed words related to water supply: *kha 'source', 'ča $a \bar{t}$ 'well', *yawiya 'drain channel'. Excavations have shown that the people of Gonur achieved amazing skill in handling water. In order to prevent water from eroding the walls of houses, the architects laid a whole system of drainage channels under the royal palace. ${ }^{6}$

The most extensive category of loanwords refers to religion and ritual, which is not surprising. Gonur and other cities in Bactria and Margiana were full of temples. Sarianidi discovered many different temple complexes in Gonur: the

4 The Andronovans traded cattle, horses, and metal for agricultural products and luxury goods.

5 A. Lubotsky, "The Indo-Iranian Substratum," in Early Contacts between Uralic and IndoEuropean: Linguistic and Archaeological Considerations. Papers presented at an international symposium held at the Tvärminne Research Station of the University of Helsinki 8-10 January 1999, ed. Chr. Carpelan, A. Parpola, P. Koskikallio (Helsinki: Suomalais-ugrilainen seura, 2001), 301-17.

6 Sarianidi, Margush, 222-23. 
temple of fire, the temple of water and yet another temple, which he called the temple of Soma/Haoma. In one of the premises of this temple, archaeologists found "a brick elevation with vessels embedded in it; the whole structure is fixed with a thick layer of plaster smear. The laboratory analysis of the vessel contents revealed hemp residues." ${ }^{77}$ Similar temple premises were found during the excavations of a huge cult complex Togolok-21, where, in addition to hemp, the remains of ephedra and poppy-seeds have been preserved. ${ }^{8}$ These rooms were used to prepare intoxicating cult drinks, which were then used in ritual ceremonies. According to Sarianidi, this ritual can be directly compared to the well-known Aryan ritual of the cult drink, called Soma by the Indians and Haoma by Iranians. This view is difficult to disagree with, but it does not imply that the people of Gonur were Aryans. It is much more probable that the Aryans first got acquainted with the Soma/Haoma cult in Central Asia, because other Indo-European peoples do not have these traditions. The secondary nature of this cult among the Aryans is eloquently illustrated by Indo-Iranian loanwords.

The word soma/haoma (Sanskrit sóma, Avestan haoma) itself is inherited and simply means 'squeezing, juice, extract', but the name of the plant from which this juice was prepared is most likely borrowed ( ${ }^{*}$ anću). Also borrowed are the words *magha 'ritual offering, sacrifice,' *atharwan 'priest', *ućig 'priestly function', * ${ }_{r} s ̌ i$ 'seer', *bhišaj 'medicinal herb' (medicine was always the work of priests) and the names of some deities *Carwa, *Indra, *Gandharwa.

Thus, we can conclude that the Indo-Iranian cult of Soma/Haoma, described in detail in the Vedic texts and in the Avesta, the sacred book of the Zoroastrians, was adopted by the Aryans from Bactria and Margiana.

What other words did the Aryans borrow in Central Asia? Quite many names of animals and birds: *uštra 'camel', *khara 'donkey', *kacyapa 'turtle', *kapauta 'pigeon', “yajhuka 'hedgehog', "matsya 'fish', *warājha 'wild boar'. Since the Aryans came to Central Asia from the north, it is clear that they were not familiar with camels and donkeys. Camels, which had been domesticated in Turkmenistan at the beginning of the third millennium BCE, played a particularly important role in the culture of Bactria and Margiana. They were placed in graves as sacrificial animals, and their images were used for decorating vases and other household items ${ }^{9}$.

As is usual in such cases, the Aryans also adopted the urban fashion: hairstyles ( "kaića-/gaića 'hair', "stuka 'plait of hair'), clothes (" atka- 'cloak', " pawastā

7 Ibid., 189 .

8 Ibid., 174 .

9 Sarianidi, Gonur Depe, 237-38. 
'fabric', *suć ‘needle', *daća 'frills'), and utensils ( *kapāra 'dish', *naij(s) 'spit', *wāć 'axe, knife'). It is quite possible that this last word refers to typical cult axes found in large numbers by archaeologists in Bactria and Margiana. ${ }^{10}$ From an archaeological point of view, the word "gadā 'mace, rod' is also interesting, since it may designate stone rod-scepters of Bactria and Margiana. ${ }^{11}$

Let's summarize. Analysis of the vocabulary of the Indo-Iranian languages shows that the Aryans were nomadic pastoralists and can be identified with the Andronovo steppe culture. Although they could in no way have been involved in the foundation of the BMAC civilization, the Aryans were in Central Asia at the beginning of the second millennium вСE and maintained close contacts with the people of Bactria and Margiana, who were culturally much more advanced in some areas. These contacts led to a large number of loanwords in the Proto-Indo-Iranian language. In this way, we were able to compile a list of BMAC words, albeit refracted by the prism of borrowing.

Of course, the next obvious question is whether we can determine what language it was, on the basis of this list. Unfortunately, all attempts so far have been in vain: these words do not resemble any other known language. There is yet another way: to identify the phonetic and grammatical peculiarities of the list and try to compare them with existing languages. But even here the efforts of the linguists have not led to the desired result, with one exception: the linguistic peculiarities of the list fully coincide with the peculiarities of words borrowed by Indo-Aryans after their separation from Iranians, that is, those words that were borrowed into Sanskrit when future Indians crossed the Hindu Kush and settled in the Punjab, in present-day Pakistan. ${ }^{12}$

For instance, in the oldest Sanskrit text, the Rigveda, we find a considerable number of agricultural terms, which are all clear borrowings: lấngala- 'plough', sírāa- 'ploughshare', kinnăra- and kinā́sa- 'ploughman', úrdara- 'granary', khārí'measure of grain', khála- 'threshing floor', odaná- 'rice-dish', tílvila- 'fertile', ulúkhala- 'mortar', kārotará- 'sieve', múla- 'root', phála- 'fruit', púspa- 'flower', pippala- 'sweet fruit', urvāruká- 'cucumber', etc. These words have no Indo-European etymology and many of them have a strange appearance: voiceless aspirates $k h, p h$, long vowels in unusual positions (type kinnára-), "suffixes" -śa-, $-p a$-, to mention but a few features.

If we look at this state of affairs from the viewpoint of Sanskrit, we can discern two different layers of loanwords: one of the Indo-Iranian stage (shared

10 A. Parpola, "The Mohenjo-Daro axe-adze: A Vestige of Aryan Immigrations to Central and South Asia?" Current World Archaeology 7.2 (2015): 14-15. Compare also Sarianidi, Gonur Depe, 281; Sarianidi, Margush, 102-3.

11 Sarianidi, Margush, 228-29.

12 Lubotsky, "The Indo-Iranian Substratum," 305-6. 
with Iranian languages), and one of the Vedic stage (without Iranian cognates). These two layers are distinguished not only by the presence vs. absence of Iranian cognates, but also by their semantics. The layer of agricultural terms in Vedic Sanskrit signals a change in the lifestyle of Indo-Aryans and the growing importance of agriculture in their subsistence.

How can we account for the peculiar fact the two layers look as if they have been borrowed from the same language (or from two closely related languages)? This would mean that the language spoken in the BMAC and the language which was spoken in the Swat valley and the Punjab were quite similar, if not identical. The similarity of the two languages is all the more surprising as the BMAC and the Indus Valley Culture do not have much in common archaeologically, and it seems unlikely that their inhabitants spoke the same language. It seems therefore worthwhile to seriously consider another scenario. ${ }^{13}$ It seems attractive to assume that the southward movement of Indo-Aryans was simultaneous with the decline of the BMAC and was even triggered by it, since the profound changes in the economy of the BMAC would have forced the Indo-Aryan pastoralists to look for new markets. In the situation of an economic and political crisis, it is only to be expected that in their movement, the IndoAryans were joined by a sizable group of the BMAC people, who would bring their culture and the agricultural lifestyle with them.

This scenario may account for the prolonged contacts of the Indo-Aryans and the BMAC people in the Swat valley and the Punjab and, consequently, for a large number of loanwords when the Indo-Aryans started to get settled and to learn agriculture. At the same time, it perfectly explains the fact that "intrusive BMAC material is subsequently found further to the south in Iran, Afghanistan and Pakistan." ${ }^{14}$ As we know from major people movements of the past, they often were multiethnic, and a joint movement of Indo-Aryans and the BMAC people would not be surprising at all.

It would be nice to hear from the geneticists whether this scenario is in line with the genetic evidence. In view of the many samples from the necropolis in Gonur, we will undoubtedly hear more about this issue in the future. Up till now, the linguistic scenarios have time and again found support in the analyses of ancient DNA. Will this also here be the case?

13 This scenario has been suggested to me by my colleague Maarten Kossmann.

14 J.P. Mallory and D.Q. Adams, Encyclopedia of Indo-European culture (London: Fitzroy Dearborn Publishers, 1997), 73 . 